\title{
脂肪食の労働効率に及ぼす影響 \\ Effect of Fat Diet on the Efficiency of Work
}

\author{
第 2 報 植物油を用いた場合 \\ Report II When the Vegetale Oil was Used \\ 国立栄羬研究所栄養生理部 (Division of Physiology, the National Institute of Nutrition)

$\begin{array}{lll}\text { 長嶺 } & \text { 晋吉 (S. Nagamine) } & \text { 久我 達郎 (T. Kuga) } \\ \text { 河田 } & \text { 正治 (S. Kawada) } & \text { 山川喜久江 (K. Yamakawa) } \\ \text { 大島壽美子 (S. Oshima) } & \text { 鈴木慎次郎 (S. Suzuki) }\end{array}$

In this experiment the vegetable oil(soybean oil)was used as source of fat component of the experimental high-fat diet in place of the butter fat used in the previous experiment (Report I, Jap. J. Nut., 12, 62, 1955). The fat content in high-fat diet was 34 per cent of the ingested total calories as shown in table I. The experimental periods were divided into following threeperiods : at first high-carbohydrate diet for 3 days, next high-fat diet for 5 days, and at last high-carbohydrate diet for 2 days. During these periods the running of about 7500 meters on the treadmill was performed for 50 minutes after 3 hours of breakfast every day, as shown in table 2. The other experimental methods were the same as in previous experiment.

The results obtained were as follows :

1) In comparison of the work metabolism in high-fat diet period with that in high-carbohydrate diet period, there was no difference in $\mathrm{O}_{2}$ consumption per the same amount of work, volume of expired air and $\mathrm{CO}_{2}$ production were less, accordingly respiratory zuotient lower in high-fat period, as shown in table 3. These results coincided with the previous experiment. It seems that the high fat diet acts favourably upon the work metabolism, as described in previous report.

2) Amounts of urinary acetone bodies per day were in the range of normal value in the previous experiment using the butter fat of about 30 per cent calories, but in this experiment using the vegetable oil of about the same amount as butter the urinary acetonebodies increased apparently as shown in figure 1 and table 4.

It is concluded from the results that high fat diet has an availability to the work metabolism, however the content of the fat of 30 percent calories in the diet is over the optimum amount for Japanese when the vegetable oil was used.

先に第 1 報として, バターを用いた場合の高脂肪食（約30\%カロリー及び50\%カロリー）の労働代謝に及 ぼす影響について報告したのであるが，今回はバターに換えるに植物油を以てした高脂肪食の労働代謝に及 ぼす影響について検討を試みた。 
実験方法 実験方法は前回と殆えど同様で, 被検者は前回と同一人の健康な青年男子であった。被検者は やはり実験期間中実験室に起居せしめて一定の生活条件下におかれた。実験期間は10日間で，最初の 2 日間 は高糖質食, 次で 5 日間は高脂肪食, 後 2 日間は再び高糖質食として, この期間毎日一定の労働が朝食後 3 時間目に50分間負荷された。実験食は第 1 表に示すように，前回の実験の場合とその構成に大差なく，高脂 肪食において前回用いられたバター $100 \mathrm{~g}$ の代りに植物油 (大豆油, 日新製天ぷら油) が $80 \mathrm{~g}$ 用いられた。

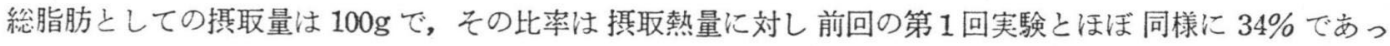
た。1 日攝取熱量は負荷労働のための消費熱量 $400 \mathrm{Cal}$ が加えられて 20052Cal とされた。動蛋は前回同様 に分析既知の牛罐の肉質部が用いられた。ビタミン類は必要量が摂取され特にピタミンAが て約 4000 I.U., B が $0.5 \mathrm{mg}$ 経口的に与えられた。

Table 1. Experimental Diets

\begin{tabular}{c|c|c|c|c|c|c|c}
\hline \multirow{2}{*}{$\begin{array}{c}\text { Diets } \\
\text { Cals./day }\end{array}$} & \multicolumn{3}{|c|}{ Grams per day } & \multicolumn{2}{c}{ Distribution of calories (\%) } \\
\cline { 2 - 6 } & & Fat & Carbohyd. & Prot. & Fat & Carbohyd. & Prot. \\
\hline High-carbohydrate & 2652 & 20.5 & 533.0 & 83.8 & 7.0 & 80.4 & 12.6 \\
High-fat & 2652 & 100.5 & 353.0 & 83.8 & 34.1 & 53.3 & 12.6 \\
\hline
\end{tabular}

* contains 80 grams of soybean oils.

** contains abaut $44 \%$ animal proteins.

Table 2. Amounts of Work Performed with a Treadmill

\begin{tabular}{l|c|c}
\hline & $\begin{array}{l}\text { High-Carbohydrate } \\
\text { diet period }\end{array}$ & $\begin{array}{l}\text { High-fat diet } \\
\text { period }\end{array}$ \\
\hline \begin{tabular}{l|c} 
Revolution per minute \\
$\begin{array}{l}\text { Running distance (meters) } \\
\text { per minute }\end{array}$
\end{tabular} & 114 & 115 \\
$\begin{array}{l}\text { Total running distance } \\
\text { per 50 minutes (meters) }\end{array}$ & 7500 & 7600 \\
Paces per minute & 164 & 164 \\
Relative metabolic rate & 7.6 & 7.7 \\
\hline
\end{tabular}

労作としては今回は トレッドミルが用いら れ，作業量としては第 2 表に示す如く, 消費 熱量にして約 $400 \mathrm{Cal}$, R.M.R.として約 8.0 であった。

しかし両食期の間に 表でみられるように， 若干の差異が生じ, 脂

肪食期において平均約 $1 \%$ 高い労働量となった (50分間に $100 \mathrm{~m}$ の歩行距離差)。本実験に入る前, 本労作 に習熟させるために約 1 週間の予備期間がおかれ，その間毎日鍊習が課せられた。

測定は朝食前先ず基礎代謝が測定され, 朝食後 3 時間目に労働が負荷される直前に安静時代謝が測られ, 次で労働代謝が労働時間 (50分) 中は 3 分おきに, 回復期 (30分) には 5 分おきに継続してダグラスパック

法により測定された。なお，脂肪代謝の状態を窥う意味において，尿中アセトン体について，小出氏の Greenberg 法の改良法により測定がなされた。同材料中数サンプルについて比較検討の意味で Behre の比 色法でも測定を行ってみた。

\section{成綪}

1. 労働代謝 毎日 50 分間課した労働代謝について, 脂肪食期と糖質食期とを両期間の平均值を以て比 
較すると第 3 表の如くである。先ず労働より回復期までの採気時間 80 分間の 全代謝についてみるに, 呼気 量は脂肪食期において 糖質食期に比し約 $2 \%$ 低いが， $\mathrm{O}_{2}$ 消費量は脂肪食期において逆に約 $3 \%$ 高く， $\mathrm{CO}_{2}$ 産生量は両食期間に大差ない値を示し， R. Q. は脂肪食期において低い(0.90対 0.93)。安静時代謝 量を除いた労働のための超過代謝量についてみても, 第3 表下段の如く上記と同様な傾向がみられる。しか しながらこれらの結果は両食期間における負荷労働量の, 僅かではあるが, 差を含むものであるから,この

Table 3. Working Metabolism

\begin{tabular}{|c|c|c|c|c|}
\hline & & $\begin{array}{l}\text { High-carbohydrate } \\
\text { period (A) }\end{array}$ & $\begin{array}{l}\text { High-fat period } \\
\text { (B) }\end{array}$ & $\mathrm{B} / \mathrm{A}(\%)$ \\
\hline 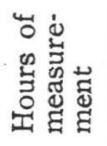 & $\begin{array}{l}\text { Working houres (min) } \\
\text { Hours of expired air collection } \\
\text { (min) }\end{array}$ & $\begin{array}{l}50 \\
80\end{array}$ & $\begin{array}{l}50 \\
80\end{array}$ & \\
\hline 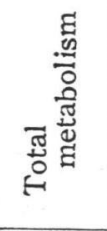 & $\begin{array}{l}\text { Volume of expired air (1) } \\
\mathrm{O}_{2} \text { consunption (1) } \\
\mathrm{CO}_{2} \text { production (1) } \\
\text { R. Q. }\end{array}$ & $\begin{array}{r}2150.2 \\
89.45 \\
86.00 \\
0.96\end{array}$ & $\begin{array}{r}2107.6 \\
91.89 \\
85.59 \\
0.93\end{array}$ & $\begin{array}{r}98 \\
103 \\
99\end{array}$ \\
\hline 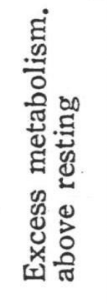 & $\begin{array}{l}\mathrm{O}_{2} \text { consumption (1) } \\
\mathrm{CO}_{2} \text { production (1) } \\
\mathrm{R} . \mathrm{Q} . \\
\mathrm{O}_{2} \text { consumed per running } \\
\text { distance } 100 \text { meters(c.c.) } \\
\mathrm{CO}_{2} \text { produced per running } \\
\text { distance } 100 \text { meters (c.c.) }\end{array}$ & $\begin{array}{r}71.45 \\
69.60 \\
0.98 \\
953\end{array}$ & $\begin{array}{r}72.21 \\
68.71 \\
0.95 \\
950\end{array}$ & $\begin{array}{r}101 \\
99\end{array}$ \\
\hline
\end{tabular}

差をなくす意味において負荷歩行距離 $100 \mathrm{~m}$ 当りで代謝量を示すと，同表にみる如く， $\mathrm{O}_{2}$ 消費量に大差な く, $\mathrm{CO}_{2}$ 産生量に於て約 $3 \%$ 脂肪食期が低い結果となる。即ち脂肪食期においては糖質食期に比し呼気量少 く, $\mathrm{O}_{2}$ 消費量は大差なく, $\mathrm{CO}_{2}$ 産生量少く, 従って R. Q.の低い傾向を有することがみられる。そして, 主観的に疲労感は両食期間に格別の差異を示さなかった。この傾向は前回のパター脂肪食実験の結果と全く 同様である。この結果は前回でも述べたように, 高脂 Fig. 1. Acetone Bodys in Urine per Day 肪食は従来いわれている食物容量としての負担軽減及 び発育に影響する問題以外に労働代謝においてもガス 交換の上に負担も軽くする有利性があることを思わせ る。

\section{2. 尿中及び血中アセトン体}

実験期間に互って1日尿についてアセトン体を定量 としたところ，第1図の如く，脂肪食に入る前の糖質 食期には平均 約 $9 \mathrm{mg} / \mathrm{day}$ であったが 脂肪食期に入る と漸増し，3 日後には著しく増加を示し，平均 22.0 $\mathrm{mg} / \mathrm{day}$ となり, 後再び糖質食に入ると漸減の傾向を 示した（平均 $19.6 \mathrm{mg} / \mathrm{day}$ )。このように大豆油を使

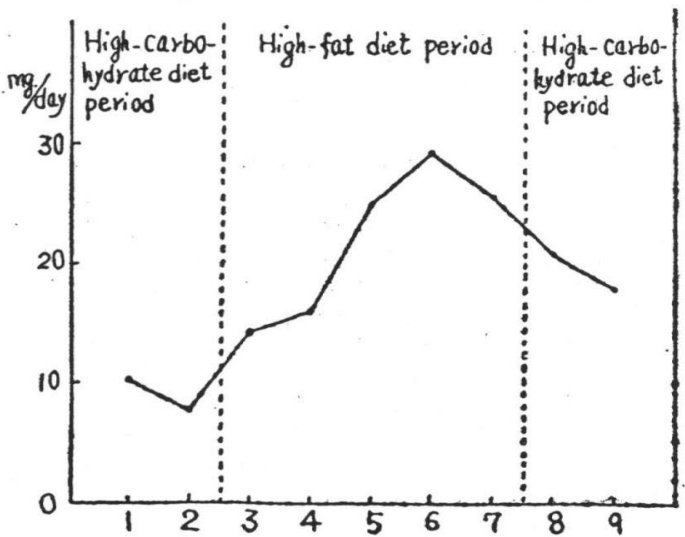


用した 34\% Cal の脂肪食においてはアセトン体の増量が認められたのであるが, 前回のバターを用いた 32 \% Cal の脂肪食の場合にはアセトン体の尿中排泄に变化は認められなかった。そこで植物油について更に アセトン体の生成を検討するために被検者 3 名 (男子2名, 女子1名) についてさらだ油 (Corn oil) を用い て本実験と同一食事構成で 3 日間追加実験を行ってみた。その結果は第 4 表の如く, 尿中排泄量は 3 人共に

Table 4. Examination of the Acetone Bodys in Urine and Blood During the High-fat Diet

\begin{tabular}{|c|c|c|c|c|c|}
\hline & & & \multicolumn{3}{|c|}{ Subjects } \\
\hline & & & $K(\delta)$ & $N(\hat{o})$ & $\mathrm{O}$ (ㅇ) \\
\hline \multirow{3}{*}{ Urine } & 1st & day & $23.0 \mathrm{mg} /$ day & $26.6 \mathrm{mg} /$ day & $82.2 \mathrm{mg} /$ day \\
\hline & 2nd & day & 27.2 & 25.8 & 38.2 \\
\hline & 3rd & day & 27.8 & 20.1 & 24.0 \\
\hline \multirow{6}{*}{ Blood } & Ai fasting & 1st day & $2.37 \mathrm{mg} \%$ & $2.79 \mathrm{mg} \%$ & $2.29 \mathrm{mg} \%$ \\
\hline & before the & 2nd day & 1.03 & 0.77 & 1.29 \\
\hline & breakfast & 3rd day & 1.43 & 1.11 & 0.86 \\
\hline & At 3 hours & 1st day & $0.84 \mathrm{mg} \%$ & $0.70 \mathrm{mg} \%$ & $0.95 \mathrm{mg} \%$ \\
\hline & after the & 2nd day & 1.14 & 0.88 & 0.81 \\
\hline & meals. & 3rd day & 1.07 & 0.60 & 0.60 \\
\hline
\end{tabular}

通常值より高い值を示している。Kは本実験と同一被検者で本実験と大体同様の排泄量である。Oの女子に おいては第 1 日目に $82.2 \mathrm{mg}$ と著しい増量を来して 2 日目，3日目と減少するのがみられる。この○におけ る傾向はOの日常脂肪摄取量が他の二人に比して少いためかと考えられる。次に血中のアセトン体について みるに, 朝食前空腹時においては脂肪摂取開始日翌朝に 3 人とも高い值を示し, その後は減少の傾向を示し ている。食後(朝食及び㡺食後) 3 時間目の平均血中値は通常の生理值の範囲を特に越えた值ではない。こ の食後の值は, 糖質が補給されたためであり, 朝食前空腹時に比較的高い值を示すのは糖質の相対的減少によ るものであろう。以上の如く植物油はその $34 \%$ ๖リーの含有食事においてアセトン体の增量を来すことが 追試でも確められたのであるが，食後数時間の血中濃度は著明に高いものではなかった。

3. 検討 高脂肪食と労働代謝に関する実験としては, 古くは 1900 年以来 Heineman や Zuntz 等の実 験があり, 両者の成績(糖質を与えた後と脂肪を与えた後の労働効率の優劣) は相反し, 1920 年 Krough and Lindhard は糖質のみを与えた場合が脂肪を与えた場合より $11 \%$ 労働効率がよいことを報告してい る。しかし Krough 等の実験は単一給与の場合である。わが国においては斎藤一等の実験があり, 氏等の 報告によると脂肪 $97.3 \mathrm{~g}$ (2009 Cal 中約 44\% Kal) の食事を捸取せしめた数日後においては攝取前に比し 鉄棒懸垂の回数が減少したとあり,また高木は犬についての実験で, 食飭中脂肪含有量が増すにつれて走行 可能時間及び走行距離が減少したと報告している。これらの成績に反し白井はバター120〜 $130 \mathrm{~g}$ 用いた脂肪 食と普通糖質食における筋労作を比較し, 脂肪食に於ては息苦しさとへばり感が軽減したと報告している。 著者等の実験は, 今回の植物油 34\% Cal の場合及び前回のバターを用いた $32 \%, 50 \% \mathrm{Cal}$ の何れの場合にお いても, $\mathrm{O}_{2}$ 消費量には大差は認められなかったが，呼気量が少く， $\mathrm{CO}_{2}$ 産生量が少く，主観的にも糖質食 期に比し何ら異常感のない結果を示した。呼気量が少いということは呼吸代謝負担を軽くするものと考える 
ことが出来, また同一仕事量当りの $\mathrm{O}_{2}$ 消費量に大差なく, $\mathrm{CO}_{2}$ 産生量少く $\mathrm{R} . \mathrm{Q}$. が低ければ, 消費熱量 としてはもしろ脂肪食期において少い傾向が考光られ(特にバターを用いた場合にこの傾向がみられた), これらの点から脂肪食は糖質食に比し短時間の労働において労働効率が不利なものとは少くとも考えられな い。この著者等の成績と前記斎藤氏等の成績との相異は脂肪含量と労作の負荷時間及び実験期間の差による ものであろうと考えられる。著者等の実験では脂肪食期注いても呼吸商は労作時平均 0.9 のlevelを示して いるように, 燃焼のための糖質に著しい不足が生じなかったがためであろう。しかし一連のてセトン体の生 成から脂肪代謝の状態を臗うに, 今回の植物油の場合には明かに尿中アセトン体の增量及び早朝空腹時にお ける血中アセトン体䀼度の増加がみられ，前回のバター $100 \mathrm{~g}$ を用いた $32 \%$ \%ロリー脂肪食時にはアセトン 体の増量が認められなかったのとは異なる結果を示した。このバターと植物油との相異については古武氏等 も彼の実験で認めたところで, 脂肪酸の相異によるものであろう。なお古武氏は脂肪の適量範囲として, バ ターを他の脂肪で代用する場合にはアセトン体排泄の上から，白鼠を用いた実験においてカロリー比として 33\% が限界であり，また学童を対象とした実験ておいて1日50〜60g（熱量比として約 20\%）が上限界で あると報告している。著者等の実験結果からは, バター脂肪食の場合は熱量比として $30 \%$ 程度までは適 量 と考えられるが、植物油を用いた場合は古武氏の実験結果と同様 $30 \%$ 熱量比以下に適量があるものと一応考 えられる。しかし Baldwin が, エスキモー人はヨーロッパ人に比し脂肪含量の高い食物に觓え得る之人種 的相異のあることを述べているように，アセトン体の生成には環境及び慣れの影響が大であるので，この考 えも考慮に入れなければならない。

結論 前回のバターを主として用いた脂肪食の場合の実験に次で，今回植物油 (大豆油)を主とした脂肪 含量約 $100 \mathrm{~g}$ (熱量比として34\%) の脂肪食を与えた場合の労働代謝に及ぼす影響について実験を行い, 次 のような結果を得た。

1. トレッド・ミルを用いた約 $150 \mathrm{~m} /$ 分, R. M. R. 8.0, 労作時間 50 分の労作において, 脂肪食期と 糖質食期との間には同一労作量当り $\mathrm{O}_{2}$ 消費量に大差は認められなかったが, 呼気量, $\mathrm{CO}_{2}$ 産生量において 脂肪食期が糖質食期に比し少く, 従って脂肪食期に R. Q. の低い特徵を示し, \&た両食期間に主観的疲労 感の差異は認められなかった。この結果は前回の実験成績と同㥞で, 植物油を用いた約 $30 \%$ 熱量比の脂肪食 の場合も短時間の労働負荷においては糖質食に比し労働効率の上には何ら不利な点はなく, むしろ呼吸代謝 にとって負担を軽くするように作用するものであることを思わせる。

2. しかし，フセトン体の生成についてみると，本実験においては，バター脂肪食30\%カロリーの場合と 異なり, 尿中アセトン体の増量及び朝食前空腹時における血中アセトン体の増加が認められた。このことか ら考虑すると，植物用它用いた場合の日本人におけ脂肪の適量は熱量比 $30 \%$ 以下あることが一応考只ら れる。しかしこの点についてはなお慣れによる生理的適応性が考虑されなければならないことは勿論であ る。

\section{交献}

1) 鈴木, 長嶺, 河田, 久我, 山川, 大島 : 栄養学雑誌, 12, 62, 1955

2) 小出, 向山, 守田 : 生化学, 25, 306, 1953

3) Heineman, H. N. : Pfluger's Arch. gesam. Physiol., 83, 476, 1900

4) Zuntz, N. : Pfluger's Arch. 'gesam. Physiol., 83, 557, 1901

5) Krough, A., and Lindhard, J. : Biochem. J., 14, 290, 1920 
6) 斎藤一, 鈴木正 : 栄養食糧学会誌, 1, 29, 1947

7 ) 高木: 労働と栄養. 1953

8 ) 白井 : 国民栄養の基準に関する研究, 1954, 21頁

9) 古武, 須川, 武田, 川口：栄養と食糧, 8, 149, 1955

10) E. Baldwin：動的生化学, 江上外 5 名共訳, 405 頁, 岩波書店, 1954

抄録

Mg 要求量と溫度及び Caについて

D. M. Hegsted et. al; J. Nut., 58. 2 (1956)

乳離れした雄ネズミ286匹についてMgを飼料 100 $\mathrm{g}$ 中 3 100mg の間で与え, $\mathrm{Ca}$ 含量を 200,600 , $1800 \mathrm{mg}$ とし周囲の温度を $13^{\circ} \mathrm{C}, 25.7^{\circ} \mathrm{C}$, に調節し て生長試験を行った。この実験によると Mg含量が3 mg以下ではCa含量が低い程よく, $\mathrm{Mg}$ 量が 6 12mg に於いては $\mathrm{Ca}$ 量の高低による差は認められなかっ た。このことは高 $\mathrm{Ca}$ 食飼は $\mathrm{Mg}$ 量が境界点或はそ れ以下にあった時は有害作用のあることをうらゔけ ている。なお $\mathrm{Mg}$ の環境温度による実験では低温度 $\left(13^{\circ} \mathrm{C}\right)$ においては体重増加率の最大值が低く, 例え ば $25.7^{\circ} \mathrm{C}$ で $25 \mathrm{mg}$ の場合を, $13^{\circ} \mathrm{C}$ で50 $\mathrm{mg}$ と比較 した場合には最大増加のための要求量の差は約 2 倍. であった。等しい体重増加を得るには食慨瓦当り の所要 $\mathrm{Mg}$ 量は $13^{\circ} \mathrm{C}$ の場合には $25.7^{\circ} \mathrm{C}$ の場合の 約 4 倍程高かった。

又著者等は $\mathrm{Mg}$ の代謝を調べる目的で $\mathrm{Mg}$ の平衡 試験も行って居り, 其結果は, $\mathrm{Mg}$ 平衡は摂取量 に関係し, 平衡維持のために要求される $\mathrm{Mg}$ 量は寒 い部屋の場合幾分大きい事が示されている。

(早川 德子) 